This is the final pre-publication version of a book chapter from:

Michael Bourdillon and Jo Boyden (eds) (2012) Childhood Poverty: Multidisciplinary Approaches, London: Palgrave Macmillan

\title{
Child Agricultural Work in South Africa: A Contested Space ${ }^{1}$
}

Andrew Dawes, Judith Streak, Susan Levine, and Deborah Ewing

\section{[A] The contested developmental space of children's work ${ }^{2}$}

Children grow up within multiple sociocultural spaces that structure activities and learning according to local notions of what is appropriate for their development (Super and Harkness 1986; Miller and Goodnow 1995; Rogoff 2003: 18-24). Contradictions across these spaces may be particularly sharp in modernizing societies where long-standing local 'traditional' practices and ideologies, such as the duty to contribute to family economic wellbeing, confront modern rights-based ideologies embedded in instruments such as the Convention on the Rights of the Child, and the African Charter on the Rights and Welfare of the Child. While they seek to advance the rights of all children to protection and development, these instruments are also forces for the globalization of the state of childhood and child rights (Myers, 
2001: 39; Boyden 1990: 194). The purpose of this chapter is to explore the experience of children who engage in agricultural work in South Africa as they grapple with the challenges of rural poverty, obligations to support kin and community, and the demands of school (Bourdillon 2009).

In the poor communities of the global South, significant numbers of children engage in paid and unpaid work. Poverty is a common factor in the lives of working children; however, it is by no means the sole reason for working (Bourdillon 2009; Jensen and Nielsen 1997: 423).

As Myers (2001: 43) notes, it is not children's work per se that is at issue in concerns about its impacts: rather it is the form and organization of their work activities. Primary concerns include potential negative impacts on schooling, health, and psychosocial well-being (see for example, Dorman 2008; Jensen and Nielsen 1997; Myers 2001; Patrinos and Psacharopoulos 1995; Woodhead 2004). At the same time, potential benefits to children working under non-hazardous conditions have come to be recognized (Myers 2001; IPEC 2002: 3). Children may learn skills valued in the local community, and may take pride in assisting with tasks that support the economic well-being of the household, thereby enhancing their self-esteem (Woodhead 2004).

There is in much of the literature greater focus on the risks to children than the possible benefits of working. The limited number 
of developing country studies available point to inverse relationships between the extent of children's economic work and their school performance. Also, economically active children are also more likely to repeat grades, drop out, and miss school (Orazem and Gunnarsson 2003: 21; Allais et al. 2008: 15). However, as Basu and Tsannatos (2003) note, working children may not be pushed out of school by work, but may drop out after repeated failure, and the cost of fees, uniforms, and books may promote exclusion. Schools themselves may be so dysfunctional that children either do not progress or leave (Anker 2000; Brown 2001).

Research on the health impacts of different forms of child agricultural work is limited. However, use of dangerous equipment, exposure to pesticides, long hours, transport risks, extreme temperatures, excessive noise, and large animals have been identified as significant risks (Dorman 2008: 30).

Little attention has been paid to psychosocial outcomes, one of the concerns that underpin child labour policy (Piotrkowski and Carrubba 1999). Some studies suggest that this should be a concern. For example, in Ethiopia Fekadu et al. (2006) found child workers more likely to warrant a psychiatric diagnosis than their non-working counterparts. However the causal relationship is not clear as it is not known whether their mental condition may have resulted in their being put to work. Physical and sexual abuse 
have been identified in several studies of working children (for example, Hadi 2000; Gharaibeh and Hoeman 2003). Abusers include adult supervisors and fellow workers.

There is a need for more research on psychosocial outcomes research which balances risks with the potential benefits of children's work. Such an approach is illustrated in Table 16.1, which is drawn from Woodhead (2004), whose formulation recognizes that both positive and negative outcomes may be possible (depending on the age of the child and the nature of the work), and that the two can co-occur (but where they do, benefits cannot cancel out harm).

\section{[Table 16.1 here]}

We turn now to discuss findings of a South African study to illustrate both negative and positive consequences of children's agricultural work, and the dilemmas they face as they respond to cultural and economic demands. In this chapter we examine the manner in which South African children living in rural areas negotiate tensions between compulsory schooling and work in commercial, subsistence, and agricultural settings, and how they experience the risks associated with their agricultural activities. We also explore perceptions of the causes of child work by children, parents, and other adults. The data for the paper are 
drawn from a study that included survey and qualitative data; our focus is on the qualitative findings (Streak et al. 2008). ${ }^{3}$

\section{[A] Child agricultural work in three South African communities}

Following ILO Convention 138, South African law forbids

employment of persons under 15 years of age, and restricts involvement in hazardous agricultural activities to adults.

Schooling is free and compulsory until the age of 15 . However, schools are permitted to charge fees for expenses not covered by the state, and all schools use this opportunity. A 'no fee' policy allows for schools serving the poorest communities to waive fees and receive additional state funding. Children are required to wear uniforms and, while text books are free, other equipment must be provided by the child.

The child agricultural labour literature in South Africa is sparse. Bourdillon (2009) provides a review of the legislation and research. We will highlight key aspects here. Apart from policy reports and commissioned studies, one thesis (Levine 2000) and two peer-reviewed journal articles are evident (Levine 2006; and Duncan and Bowman 2008). There are also several reports based on the Survey of Activities of Young People (SAYP), which covered children aged 5 to 17 years and was conducted in South Africa in 1999 (Orkin 2000; Statistics South Africa 2000). The SAYP found 
that 45 per cent of working children were in agriculture, and that the subsistence form predominated over employment in the commercial sector. Most of the children carrying out many hours of work in unpaid subsistence agriculture were located in former black 'homeland' areas, to which most persons classified as African under the apartheid system were restricted. Poverty was identified in the survey as the major driver for children's involvement in agricultural work.

\section{[B] Methods}

The study was conducted in three sites identified as typical of the major types of South African agricultural activity and in which child agricultural work is known to be common.

The Worcester area in the Western Cape has a long history of exploitive labour practices and use of child workers to produce grapes for the wine industry and for export fruit markets. There is no subsistence agriculture other than small family gardens. The political economy of the area reflects the deep structural inequalities in the wine industry and the historical rural apartheid economy. The discrepancy between rich and poor in the area is striking, with wealthy farmers living a few metres from workers who commonly live in abject poverty. Prior to the end of apartheid, workers were paid in part with tots of wine (known as the 'dop system'). While the practice is now outlawed, alcohol abuse is rife in the area. The dominant language of children living 
on wine farms in this study site is Afrikaans.

A second sample of children resides in the rural and traditionally oriented area of Msinga Kwazulu-Natal. Msinga has been identified as one of the four most deprived areas in this region (Noble et al 2006: 41). Unemployment is high and migration for work is common. Commercial mixed farming (predominantly white-owned) and subsistence agriculture are undertaken. According to local informants, acceptance of child participation in subsistence and commercial agriculture is long established and part of traditional life. IsiZulu is spoken in this area.

The third study site is located south of the Kruger National Park in the Nkomazi Municipality of Mpumalanga Province. Both commercial and subsistence farming occur, with the majority of commercial farms owned by whites. According to the Nkomazi Integrated Development Plan (Nkomazi Municipality 2005/06: 12 ), the main product is sugar cane followed by fruit and forestry plantations. Subsistence agriculture plays a key role in providing income and food for the poor rural black population in the area. There is significant income inequality between blacks and white farmers, with the former living well below the poverty line (Provide 2005). Adult participants indicated that most of the child participants came from households that had a plot on which they produced food for the household. The main language of the area 
is siSwati.

A convenience sample of 1030 boys and girls aged 12 to 16 years participated in a survey during school hours. The samples are not random although likely to be fairly typical for the areas studied.

Items in the survey instrument included questions on work in the past year, and its frequency and length and time of spell. Participants were asked whether school was affected by work (for example, whether they were late, had insufficient time for homework, or missed school), and why they worked (for example, to earn money as a community duty, or to learn skills). The nature of the work (for example, herding cattle, pruning vines), the conditions (heat, cold, use of dangerous implements, abuse, and so on), and the outcomes (injuries and psychological outcomes) were covered.

Psychosocial impacts were measured using five items drawn from the Social and Health Assessment (SAHA) that captured anti-social behaviour (substance use and assaults perpetrated), as well as anxiety and depression (Ruchkin et al. 2004). The number of items was restricted in order to reduce the length of the instrument.

In the absence of directly supplied data on adult economic status, child deprivation was assessed by summing the number of items checked from a list of 12 assets that children had agreed 
were basic necessities for their age group. The checklist was based on a study of perceived necessities of both adults and adolescents conducted in similar communities (Barnes 2009; Wright 2008). Hunger was measured by asking whether the family had had to go without food because of lack of money in the past month. In addition, children reported on whether or not their parents were employed, and whether or not one or both parents were alive.

Qualitative data was derived from child focus-group interviews and adult interviews. In each study area, group discussions were held with an average of ten randomly selected school children from those who were identified in the survey as working in agriculture. Out-of-school working children (between the ages of 11 and 18) participated in separate sessions.

Two techniques were developed to gather information on perceptions of work, its benefits and hazards. In a body-mapping exercise (Solomon and Morgan 2007: 8-9), children drew outlines of each other's bodies on newsprint and then wrote or drew on their pictures in response to questions about their lives, including: 'Where do you feel safe? Who is the most important person in your life? What kind of work do you do? What is the best/worst thing about working? What injuries have you experienced?' Photographs of working children were also used to generate discussion of participants' experiences. 
Adults, including commercial farmers, parents, teachers, social workers, and other professionals, were also interviewed to obtain their views on the appropriateness of children's work in agriculture, its causes, and its effects on schooling and health.

Ethical procedures were followed with adults giving consent to their children's participation, and children giving their assent.

\section{[A] Findings}

\section{[B] Incidence}

We report briefly on the incidence of children's agricultural work. 17 per cent of the children in the Western Cape site, 59 per cent in the Mpumalanga site, and almost the all those in the KwaZuluNatal site (92 per cent) participated in some form of agricultural activity. It was not uncommon for children to work in both family subsistence and community-owned agriculture. Only 27 per cent of the sample worked exclusively for pay in privately owned commercial agriculture.

Girls and boys were equally likely to report work in subsistence agriculture (which differs from the SAYP findings, according to which boys were more likely than girls to undertake this form of work), but boys were more likely to be employed in the commercial agricultural sector. 62 per cent of girls as against 57 per cent of boys had undertaken domestic work outside their own families in the past year; 45 per cent of this group were paid 
for their time.

94 per cent of the sample had undertaken domestic work in their own homes in the past year, with cooking, cleaning, and collecting firewood being most common tasks. Girls (98 per cent) and boys ( 90 per cent) showed similar rates of participation but in different tasks.

[B] The complexity of causes and consequences

Children were asked why they worked in agriculture.

Participants who said they worked without pay in subsistence agriculture on family or community plots were provided with three options to indicate their reasons (they could check more than one option): to learn things they needed to know; out of duty to family; out of duty to the community. 70 per cent indicated that they undertook this activity out of duty to family or community, and 46 per cent wanted to learn agricultural skills.

Children working for pay were asked why they needed to earn money (they could give more than one reason). 70 per cent worked in order to have cash in order to meet their own needs, while 36 per cent were working in order to support their families. 28 per cent saw paid work as an opportunity to learn agricultural skills.

In this sample, economic work was as much a solution to personal deprivation as it was undertaken to support the family. 
As will be evident below, it was common for children to use their earnings to purchase uniforms and items for school.

Focus-group conversations revealed a positive aspect of their work in children's awareness of the importance of their activity to the development of practical abilities relevant to their living environment and possible future employment.

Unsurprisingly, poverty emerged as a prominent cause of children working to support themselves and their families. Statistical analyses (see: Streak et al. 2008 for full details) showed that working children possessed significantly fewer assets than children who did not work, and children working in both subsistence and commercial agriculture reported significantly fewer assets than those working in subsistence activities alone.

A further indicator of economic distress is that more working children experienced household hunger because of a lack of money (47 per cent) than those that did not work (21 per cent) and again, more children working in both subsistence and commercial agriculture experienced hunger ( 64 per cent) than those working in subsistence farming alone (35.5 per cent), or in commercial agriculture only (45.6 per cent). And finally, those who reported parental unemployment were more likely to be working in agriculture. On all these points, differences between the categories are statistically significant (see Streak et al. 2008). The data from the survey indicate that overall, children who work 
in agriculture (of any kind), are more deprived than those who do not, and that children from subsistence farming areas who also work in commercial agriculture are the worst off.

Food insecurity is illustrated by a teacher's observation: 'Children are taking home food from school feeding schemes to feed their families.'

The impact of poverty is reflected in the comments of a farmer about parents' inability to finance schooling: 'At one school, you may have 50 per cent not paying. Even if you ask parents to pay R10 [US\$1.25], they can't. Some are getting a [social] grant but need all that money to buy food.'

Working children's comments are instructive:

'We don't have enough money for food and clothes ...

Some of us give all our money to our mothers for food when we work.'

'Because we are suffering and we need money, we go and work on a farm, but it is not a nice job.'

'We are able to support our families and our brothers and sisters.'

'[I work] so I can buy a uniform for school.'

Despite the hardship, there is a sense of positive identity and pride gained from working evident in the last two quotes, which illustrate the positive indicator of self-esteem as a psychological 
outcome from work in Woodhead's (2004) 'personal identity and valuation' psychosocial domain. There is also a sense of social competence, moral maturity, and personal agency in these accounts. They suggest self-efficacy rather than hopelessness in the face of a very difficult situation.

The fourth quote illustrates the paradox faced by a poor child in a country within which education is a fundamental right, but where barriers to access are raised by the costs of uniforms.

Adult comments, listed below, illustrate the manner in which reasons for children working reflect multi-layered repertoires of traditional obligation, learning relevant skills, moral development, and contributing to family survival. Woodhead's culturally valued competencies are present, particularly in the final quote from a rural subsistence farmer and parent:

'They are learning but they are also helping us ... They are taught respect.'

'They learn skills to make gardens - dirty hands bring them a beautiful plate of food on the table but they don't like to see themselves getting dirty.'

'It teaches them important skills [that] will not leave them ... even without a job they can still produce food.'

'It is about a boy's future ... building a kraal, 
taking responsibilities as an adult man.'

\section{[B] Negative Impacts}

Negative consequences were also reported (Table 16.2). Hazards were present in 90 per cent of cases; and 63 per cent of participants reported a negative health impact.

\section{[Table 16.2 here]}

Commonly reported hardships, regardless of the type of agriculture were excessive heat, thirst, long hours, physically and psychologically abusive treatment by employers or fellow workers, and working with dangerous substances.

Children said they felt conflicted about work and its impact. On the one hand, there is the benefit of economic or community contribution together with opportunities to learn skills. On the other, there is the high probability of injury and abuse. A child commented, 'I don't like it when they treat me bad, like shouting at me while I'm working and using harsh words.' Another youth explained, 'If you get cut or hurt, they ask you why - are you stupid?' An example of an injury depicted on a body map is shown in Figure 1.

[Figure 1 here] 
Humiliation was reported by children living and working on white commercial farms: 'When the farmer's children drive past they shout, "Plaasjapies" [farm idiots] and we cannot say anything back because they are the Boer's child.' The term 'boer' is standard Afrikaans for 'farmer'. However, it is also used by black South Africans to signify relationships of power and white oppression, as in this example.

Relevant here is Woodhead's (2004) construct of psychosocial domains in terms of personal identity and valuation. As much as working children gain self-respect through work, among the negatives is stigmatization of being a poor (stupid) farm worker's child.

Statistical analysis of the survey data revealed patterns in the psychosocial impacts. Taking all types of agricultural work together, working children reported significantly higher levels of anxiety and depression than those not working at all. However, we cannot be sure that these outcomes are solely a function of their work situation. These children may come from more problematic family backgrounds (with alcohol abuse, for example). There were no differences in regard to anti-social behaviour items.

When we examined sub-types of work, children who only worked in subsistence agriculture reported significantly less anxiety and depression than those working only in commercial 
agriculture or in both types. We cannot be sure of the causal pathways here, but those with negative outcomes may be coping with a triple burden of schooling, work for kin, and wage labour. Subsistence work alone may be less troubling because it is coupled to a normative expectation to do such work in the service of kin and community.

In addition to speaking about their psychological stress related to treatment by farmers (of them or their parents) children highlighted that they felt bad about how they were treated by their parents and other adults when the adults drank. One boy said, 'On the farms when the adults get drunk they start fighting with children ... It causes me a lot of stress to see my mother drunk. I get beaten when I ask my mother why she drinks.'

\section{[B] Impact on schooling}

The participants were asked approximately how much time they spent working in a week. Responses indicated that children's estimation of hours worked was not reliable, with many saying that they had worked more hours than were possible in an average week when other demands on their time - such as school - were factored in. Given this problem, hours worked were not used for purposes of analysis. The consequence was that unfortunately, we were not able to examine relationships between time spent on work and on schooling and resultant impacts. 
The survey established that children mainly worked in agriculture before or after school, over weekends, and during school holidays. Seasonal work affected these patterns. We were unable to examine the effects of agricultural work on child outcomes as we did not have access to the necessary information. However, we found that work interfered with school in 25.6 per cent of cases (missing school; arriving late; too tired to do homework; and so on). Statistical analyses showed that work impacted to the same degree on schooling regardless of the type of schooling. Of those who reported a negative impact of work on school, 25 per cent were girls and 32 per cent were boys.

When asked about the impact of their work on schooling in group discussions, children said that their agricultural work often caused them to be late and absent and did not comment on what this implied for their education outcomes. They missed school most at harvest time and work before school made them late. Work also interfered with leisure activities. For some, the only negative outcome occurred when they were not paid on time (when they worked during holidays): they were then unable to buy uniforms and were refused entry to school.

It is not only enrolment or attendance that can affect school outcomes. Children can be in school, but, having worked in the early morning or over the weekend, there is little time for the homework that is necessary to progress through higher grades. 
According to one teacher:

It makes them tired ... They don't have enough

time ... It can interfere with their school. When it

is time for cattle to be disinfected, a lot of

children are absent. It is the older ones and

around 30-50 are away for dip day on a Monday

or Tuesday. It happens all year round.

Teachers noted that many children live in homes where alcohol abuse and violence co-exist with poverty, and where the family shares one room. It is not surprising under such conditions that children are likely to fail grades and drop out. And when they do, it is not only to go and work on farms.

\section{[A] Reflections}

These findings, while not based on a random sample, are likely to be a fair reflection of the situation of children living in similar circumstances. Three central points are evident.

First, while poverty is clearly a fundamental cause of children's involvement in agricultural work, particularly in paid work, obligations to kin and community are important contributors. In this study, we find that when subsistence and privately owned commercial agriculture are compared, rates of exposure to work hazards and compromised schooling are similar. More children working in commercial agriculture (both 
community-owned and private) reported that work impacted on their health, although nearly half of those working in subsistence agriculture also experienced an impact on their health. Focusing on exploitation in paid employment has led to a lack of attention to the abuses and hazards for children working on family plots or communal lands.

Second, while work interferes with schooling, our evidence suggests that wider contextual factors such as home conditions and poor school environments are also significant barriers to being able to benefit from education. For example, in one high school classroom we observed 80 pupils with one teacher - a very challenging educational environment for both teacher and students.

Third, the study confirms that from child and adult perspectives, participation in agricultural work (paid or not) has both risks and benefits. In particular, for children who work in both unpaid subsistence and paid commercial settings, the psychosocial costs appear significant. That said it is important to recognize that negative psychological states are unlikely to be a function of work alone. Conditions at home are very likely to contribute to the incidence of anti-social behaviour, anxiety, and depression. In addition, unpaid domestic work is not necessarily benign and may involve exploitation that is hidden and leads to negative child outcomes. 
On the positive side, children and adults value children's work as much for its social function as for its economic contribution. Participation is valued for the transfer of important skills, in many ways more important perhaps than what is being learnt in poorly resourced and overcrowded schools.

However valuable that may be, poor rural South African children are placed in a contested set of developmental spaces. They are caught three ways: by the dictates of legislation and policy that criminalizes their employment and speaks more to the cultural practices of post-industrial societies of the North than to local rural realities; by compulsory schooling that often does not deliver quality; and by a family environment that undermines the possibility of benefiting from school, while making both paid and unpaid work (mainly in subsistence settings) a rational survival solution.

A child participant saw the contradictions: 'We are pushed by the situation, not by our parents.'

\section{References}

Allais, F. B. and F. Hagemann (2008) Child Labour and Education: Evidence from SIMPOC Surveys, Working Paper, Geneva: International Labour Organization

Anker, R. (2000) 'The Economics of Child Labour: A Framework 
for Measurement', International Labour Review 139: 257-80

Barnes, H. (2009) Child Poverty in South Africa: A Socially

Perceived Necessities Approach, Measures of Child Poverty

Project Key Report 2, Pretoria: Department of Social

Development, Republic of South Africa

Basu, K. and Z. Tzannatos (2003) 'The Global Child Labour Problem: What Do We Know and What Can We Do?', The World Bank Economic Review 17: 147-73

Bourdillon, M. (2009) 'Children's Work in Southern Africa', Werkwinkel 4.1:18-36

Boyden, J. (1990) 'Childhood and Policymakers: A Comparative Perspective on the Globalization of Childhood', in A. James and A. Prout (eds) Constructing and Reconstructing Childhood, London: Falmer Press

Brown, D. K. (2001) 'Child Labour in Latin America: Policy and Evidence', World Economy 24: 761-78

Dorman, P. (2008) Child Labour, Education and Health: A Review of the Literature, Geneva: International Labour Organization

Duncan, N. and B. Bowman (2008) 'Educational Aspirations, Child Labour Imperatives and Structural Inequality in the South African Agricultural Sector', Perspectives in Education 26: $29-43$

Fekadu, D., A. Atalay and B. Hägglöf (2006) 'The Prevalence of 
Mental Health Problems in Ethiopian Child Laborers', Journal of Child Psychology and Psychiatry 47, 954-9

Gharaibeh, M. and S. Hoeman (2003) 'Health Hazards and Risks For Abuse Among Child Labor in Jordan', Journal of Pediatric Nursing 18: 140-7

Hadi, A. (2000) 'Child Abuse Among Working Children in Rural Bangladesh: Prevalence and Determinants', Public Health 114: $380-4$

IPEC (2002) Combating Child Labour: A Handbook for Labour Inspectors, Geneva: International Programme for the Elimination of Child Labour

Jensen, P. and H. Nielsen (1997) Child Labour or School Attendance? Evidence from Zambia, Journal of Population Economics 10: 407-24

Levine, S. (2006) 'The "Picaninny Wage": An Historical Overview of the Persistence of Structural Inequality and Child Labour in South Africa', Anthropology Southern Africa 29: 122-31

Levine, S. (2000) 'In the Shadow of the Vine: Child Labour in South Africa's Wine Industry', PhD thesis, Temple University, Philadelphia, Pennsylvania

Miller, P.J. and J.J. Goodnow (1995) 'Cultural Practices: Toward an Integration of Culture and Development' in J.J. Goodnow, P.J. Miller and F. Kessel (eds) Cultural Practices as Contexts 
for Development, San Francisco CA: Jossey-Bass Publishers Myers, W.E. (2001) 'Can Children's Work and Education Be Reconciled?', International Journal of Educational Policy, Research and Practice 2: 307-30

Nieuwenhuys, O. (1996) 'The Paradox of Child Labor and Anthropology', Annual Review of Anthropology 25: 237-51

Nkomazi Municipality (2005/06) 'Nkomazi IDP, 2005/2006 Revision'

http://www.idp.org.za/documents/IDP/Mpumalanga/MP324/ 2005/MP324 2005 Nkomazi\%20IDP.pdf (accessed 15 May 2010)

Noble, M., M. Babita, H. Barnes, C. Dibben, W. Magasela, S. Noble et al. (2006) 'The Provincial Indices of Multiple Deprivation for South Africa 2001: Technical Report', http://www.casasp.ox.ac.uk (accessed January 2010)

Orazem, P. F. and V. Gunnarsson (2003) Child Labour, School Attendance and Academic Performance: A Review, ILO/IPEC Working Paper, Geneva: International Labour Organization Orkin, M. (2000) Surveys of Activities of Young People, Pretoria: Statistics South Africa Patrinos, H.A. and G. Psacharopoulos (1995) 'Educational Performance and Child Labor in Paraguay', International Journal of Educational Development 15: 47-60 
Piotrkowski, C.S. and J. Carrubba (1999) 'Child Labor and

Exploitation' in J. Barling and E.K. Kelloway (eds) Young

Workers: Varieties of Experience, Washington DC: American

Psychological Association

Provide (2005) 'A Profile of Mpumalanga: Demographics, Poverty, Inequality and Unemployment', Provide Background Paper 2005. 1.8, www.elsenburg.com/provide (accessed 6 April 2010)

Rogoff, B. (2003) The Cultural Nature of Human Development, Oxford and New York: Oxford University Press

Ruchkin, V., M.E. Schwab-Stone and R. Vermeiren (2004) Social and Health Assessment (SAHA): Psychometric Development Summary, New Haven CT: Yale University

Solomon, J. and J. Morgan (2008) Living With X. A Body-Mapping Journey in the Time of HIV and AIDS. A Facilitator's Guide. Johannesburg: REPSSI. Available at http://www.repssi.net/index.php?option=com content\&view=article\&c atid $=39 \% 3$ Arepssi-publications\&id $=49 \% 3$ Abody -mapping\&ltemid $=68$ (accessed 10 May 2010)

Statistics South Africa (2000) Survey of Activities of Young People (SAYP 1999), Pretoria: Statistics South Africa

Streak, J., A. Dawes, D. Ewing, S. Levine, S. Rama and L. Alexander (2008) Children Working in the Commercial and Subsistence Agriculture in South Africa: A Child Labour- 
Related Rapid Assessment Study, TECL report no. 52, Pretoria: Department of Labour

Super, C. M. and S. Harkness (1986) 'The Developmental Niche: A Conceptualization at the Interface of Child and Culture', International Journal of Behavioral Development 9: 545-69 UNESCO (2007) EFA Global Monitoring Report 2008. Education for all by 2015. Will we make it?, Paris and Oxford: UNESCO and Oxford University Press

Woodhead, M. (2004) Psychosocial Impacts of Child Work: A Framework for Research, Monitoring and Intervention, Understanding Children's Work Working Project Paper Series, Rome: University of Rome

Wright G. (2008) Findings from the Indicators of Poverty and Social Exclusion Project. A Profile of Poverty Using the Socially Perceived Necessities Approach, Key Report 7, Pretoria: Department of Social Development, Republic of South Africa 
Table 16.1 Indicators for psychosocial outcomes of children's work

Source: Woodhead (2004)

\begin{tabular}{|c|c|c|}
\hline Domains & Positive indicators & Negative indicators \\
\hline $\begin{array}{l}\text { Cognitive abilities } \\
\text { cultural competencies }\end{array}$ & $\begin{array}{l}\text { Intelligence; culturally } \\
\text { valued competencies }\end{array}$ & $\begin{array}{l}\text { Compromised development; } \\
\text { poor skill base }\end{array}$ \\
\hline $\begin{array}{l}\text { Personal security, } \\
\text { social integration, } \\
\text { social competence }\end{array}$ & $\begin{array}{l}\text { Positive relationships; } \\
\text { positive moral conduct }\end{array}$ & $\begin{array}{l}\text { Insecurity, inhibition, } \\
\text { anti-social behaviour }\end{array}$ \\
\hline $\begin{array}{l}\text { Personal identity and } \\
\text { valuation }\end{array}$ & $\begin{array}{l}\text { Positive self-concept, } \\
\text { high self-esteem }\end{array}$ & $\begin{array}{l}\text { Worthlessness, fear of failure, } \\
\text { shame, stigma }\end{array}$ \\
\hline $\begin{array}{l}\text { Sense of personal } \\
\text { agency }\end{array}$ & $\begin{array}{l}\text { Self-efficacy, autonomy, } \\
\text { responsibility }\end{array}$ & $\begin{array}{l}\text { Helplessness, ELC; } \\
\text { hopelessness }\end{array}$ \\
\hline $\begin{array}{l}\text { Emotional and somatic } \\
\text { well-being }\end{array}$ & $\begin{array}{l}\text { Subjective well-being } \\
\text { and health }\end{array}$ & Stress, anxiety, depression \\
\hline
\end{tabular}

Table 16.2 Negative work impacts

\begin{tabular}{lccc}
\hline & $\begin{array}{c}\text { Negative } \\
\text { impact on } \\
\text { school } \\
\mathbf{N}(\%)\end{array}$ & $\begin{array}{c}\text { Negative } \\
\text { impact on } \\
\text { health } \\
\mathbf{N}(\%)\end{array}$ & $\begin{array}{c}\text { Hazardous } \\
\text { conditions } \\
\mathbf{N}(\%)\end{array}$ \\
\hline $\begin{array}{l}\text { Subsistence } \\
\text { agriculture }\end{array}$ & $54(35)$ & $74(49)$ & $129(85)$ \\
\hline $\begin{array}{l}\text { Community- } \\
\text { owned }\end{array}$ & $13(21)$ & $46(77)$ & $55(91)$ \\
\hline
\end{tabular}




\section{Privately owned}

commercial

agriculture

$14(32)$

$27(63)$

$41(95)$

Figure 1 Part of a body map of a child's injuries sustained while working

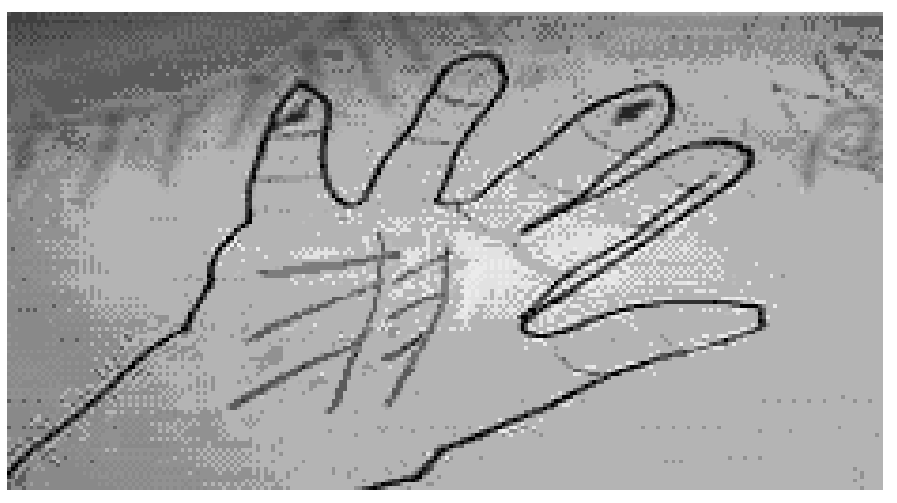

[Caption] The heavy marks on the palm and the mark at the end of the second finger were depicted in red.

${ }^{1}$ This paper is based on research contracted to the Human Sciences Research Council of South Africa by the International Labour Organization's 'Towards the Elimination of Child Labour (TECL)' South African programme. The authors are grateful for the financial support of the ILO. We also wish to express our thanks to the child and the adult participants who gave us hours of their time to share their views on child work in South African agriculture. Without the dedication of our field staff and those who helped us gain access to relevant communities, this work would not have been possible. 
We thank the reviewers for their helpful comments on an earlier draft of the paper.

${ }^{2}$ In this chapter we use the term 'work' to include light or heavy agricultural activity undertaken by children in order to contribute their time or earnings to the family or community economy. It includes those classes of work prohibited in law unless otherwise specified.

${ }^{3}$ Full details of the research are available at http://www.hsrc.ac.za/Research_Publication-21019.phtml (accessed 6 April 2010). [CK: Do we need a date accessed here, since it concerns the authors' own work?] 